\title{
Remarks: A Public Law Perspective
}

\section{A. Douglas Melamed ${ }^{\dagger}$}

The original article that Guido and I wrote, ${ }^{1}$ and its progeny insofar as I am familiar with it, address issues of private law. By contrast, I have spent most of the time since the article was written dealing with matters of public law, first in private practice and recently in the Justice Department. Most of those matters have involved antitrust law, which is fundamentally concerned with ameliorating or preventing market power and thus, in the parlance of this meeting, avoiding or minimizing the risk of holdout problems. Antitrust law is, in that sense, fundamentally in aid of property rules. Ironically, the antitrust agencies have in recent years increasingly thought it necessary to employ what I have elsewhere called "regulatory" remedies, ${ }^{2}$ many of which would here, I think, be called "liability rule" remedies.

Not surprisingly, in light of my experience, I read the papers and listened to the comments this morning from the perspective of someone who has spent the bulk of his life dealing with issues of public law. I thought I would take a few minutes to share some reactions from that perspective.

Rule 4 is alive and well-at least in Washington. As everyone knows, the traditional private law litigation process does not readily lend itself to Rule 4, particularly where there are large numbers on the plaintiff/victim/payor side, and Rule 4 is thus not common in the private litigation context. The notorious exception, the Spur Industries case, ${ }^{3}$ did not have a large number problem; maybe that is why it was able to find a use for Rule 4.

The government can overcome the large number problem, as it does in the paradigmatic eminent domain case. That much is obvious. What is perhaps less obvious is that, in the public law domain, the government uses Rule 4 all the time. For example, television broadcasters are in effect required to give up what many had thought to be their preexisting entitlement to broadcast violent programming if their viewers want to see it and their advertisers are willing to sponsor it; as compensation, the broadcasters are given free use of additional spectrum to accommodate the transition to the digital age. In a similar vein, the 1996 Telecommunications Act requires local telephone companies to make

$\doteqdot$ Principal Deputy Assistant Attorney General, Antitrust Division, U.S. Department of Justuce.

1. See Guido Calabresi \& A. Douglas Melamed, Properny Rules, Labiling Rules, and Inalienabiliy: One View of the Cathedral, 85 HARV. L. REV. 1089 (1972).

2. See A. Douglas Melamed, Antitrust: The New Regulanton, 10 ANTtrRUST 13 (1995)

3. Spur Indus., Inc. v. Del E. Webb Dev. Co., 494 P.2d 700 (Anz 1972) 
their facilities available to their would-be rivals in local telephony and compensates the phone companies by permitting them to enter into the long distance business that had previously been foreclosed to them. ${ }^{4}$ And, in at least two recent instances, the Federal Trade Commission has compromised the right of private entities to carry on their businesses by assuming oversight authority over them -in one case, a blank check to impose divestiture or other injunctive remedies as the Commission sees fit-and compensated the parties by permitting them to consummate an otherwise problematic merger. ${ }^{5}$ There are countless examples like this in the public sector. While they often have some of the trappings of a bargain, they ultimately can be called Rule 4-type remedies-or, in the case of the telephone companies and the long distance carriers whose own market positions are threatened, combinations of Rule 4 and Rule 2-because the consent of the private parties is not required.

There are many differences between these cases and the kinds of stylized private disputes that are the subject of the property rule/liability rule literature. In spite of the differences, or perhaps because of them, I suspect that analyzing the public law cases might generate useful insights about property rule/liability rule issues.

One difference between public law disputes and private law disputes is that the government entity that purports to act on behalf of the victim-complainants in a public law matter will rarely if ever have complete access to its constituents' private information. Liability rules are thus less likely to be effective in inducing disclosure of private information about the costs of conflicts when administered by proxies in the public law context than when used in the typical private law case. (Class actions and other forms of representative private litigation are something of a hybrid in this respect.)

Another difference between public law disputes and private law disputes concerns the process for deciding the amount of compensation. In private disputes, a presumably neutral decisionmaker is asked under a liability rule to calculate damages equal to its best estimate of the price that the compensated party would have insisted upon before entering into a voluntary transaction. The compensation is intended to stimulate, or failing that to emulate, the price that would be paid in a consensual private transaction. By contrast, in the public law context, the entity that decides the type and amount of compensation paid under a liability rule is often the same entity as that which represents the victim-constituents. The criteria for determining the amount of compensation to be paid under a liability rule are therefore likely to differ from

4. See 47 U.S.C. § 271(c); see also H.R. CONF. REP. No. 104-458, at 147 (1996).

5. See Hoescht AG, FTC Docket No. 3629 (Dec. 5, 1995); Eli Lilly \& Co., FTC Docket No. C-3594 (July 28, 1995); 61 Fed. Reg. 31,117 (June 19, 1996) (final consent order and Commission statement); 61 Fed. Reg. 16,794 (Apr. 17, 1996) (final consent order and Commission statement); 60 Fed. Reg. 49,609 (Sept. 26, 1995) (proposed consent order with analysis to aid public comment); 59 Fed. Reg. 60,815 (Nov. $28,1994)$ (proposed consent agreement with analysis to aid public comment). 
those used in the typical private law dispute. In a governmentally imposed Rule 4-type remedy, the compensation might be intended to satisfy core notions of fairness or constitutional requirements of just compensation or to keep the constrained private entity from folding its hand and withdrawing from the business altogether, or it might be any amount necessary to mollify political representatives of that entity.

There is another, more interesting difference between public law uses of liability rules and their private law analogues. Richard Epstein anticipated some of my observations in his comments this morning, although from a characteristically less equivocal point of view. The literature on property rules and liability rules deals with one-shot encounters between entities that have conflicting demands-a hypothetical polluter, for example, and its neighbors. The issue is whether a property rule or a liability rule supplied after the fact would reach a better result. To be sure, as Saul Levmore notes in his paper, prospective rules-either property rules or liability rules-can be fashioned on the premise that the conflict will endure. ${ }^{6}$ But such prospective rules are still after-the-fact remedies in the sense that they are imposed after the particular dispute has arisen and they are intended to deal with the specific encounter between the particular polluter and its neighbors. As a general matter, in the typical private law model, the choice of a property rule or liability rule remedy has ramifications for future disputes only to the extent that paries take into account the fabric of the law, and anticipate which remedies might be applied in future disputes, in deciding how they are going to act. ${ }^{7}$

Public law uses of liability rules, by contrast, often involve a very different situation, one that in the contemporary jargon would be called a "repeat game." In this game, for example, the telecaster knows that it has to deal with Congress year in and year out on a variety of matters, the telephone company knows that it has to deal with the Federal Communications Commission day in and day out, and so on. I suspect that the participants in these repeat games behave very differently from the entities that are modeled in the typical literature on property rules and liability rules.

Jim Krier and Stewart Schwab took a step in this direction when they talked about "synergy," by which I understand them to refer to the effect of the choice between liability rules and property rules on the capacity of parties to transact. ${ }^{8}$ And Ian Ayres and Jack Balkin wrote about incentives to invest in property. ${ }^{9}$ But they did not examine the issues from the perspective of a

6. See Saul Levmore, Unifying Remedies: Propert? Rules, Labulsty Rules, and Startling Rules, 106 YALE L.J. 2149 (1997).

7. See Emily Sherwin, Introduction: Propern. Rules as Remedies, 106 YALE L J 2083 (1997)

8. See James E. Krier \& Stewart J. Schwab, Propern Rules and Labulis Rules: The Cathedral in Another Light, 70 N.Y.U. L. REV. 440, 462-64 (1995).

9. See Ian Ayres \& J.M. Balkin, Legal Entillements as Aucnons: Properny Rules, Lubuliry Rules, and Beyond, 106 YALE L.J. 703 (1996). 
repeat game, taking into account, in particular, the importance in a repeat game of reputational interests.

My knowledge here is only anecdotal, but I can tell you from my experience that entities that believe they are playing in a repeat game behave differently. Firms that are regulated by or have ongoing relationships with particular government agencies treat those agencies very differently from the way they treat, for example, the Antitrust Division, with which they do not imagine themselves being engaged in a repeat game. Generally, firms are more compliant with their regulator than they are with a government entity with which they are not engaged in a repeat game. By the same token, the phone companies that were subject to the Modification of Final Judgement, the antitrust consent decree, after the divestiture of AT\&T, treated the Antitrust Division very differently from, and much more compliantly than, the way more ordinary alleged monopolists treat the Division. The differences, I think, go well beyond investment in property, even beyond Richard Epstein's concern about "stability of possession." 10 There is a qualitative change in the behavior of parties to a repeat game.

Some may say that this is a good thing-that the participants in repeat games internalize more effectively the costs of their conduct on others or that the gains from trade are more equitably distributed because of the change in behavior. Others, however, might lament the change, observing a loss of innovative entrepreneurship to participants in a repeat game of this nature. One's view might depend, to borrow from Carol Rose, on whether the "shadow example"ll is one of accidents, in which case heightened internalization might be regarded as a good thing, or whether the shadow example is one of contract, in which case one might either welcome a likely increase in the efficiency of transactions with the public sector or fear an erosion of imagination in private sector bargains that could result from participation in such a repeat game.

It is not clear how all this affects the choice between liability rules and property rules. I will, however, venture the following conjecture: The liability rule alternative-Rule 4 in particular-enables the government to take asserted entitlements at less than the cost it would have to incur in a regime consisting entirely of property rules. The availability of liability rules is thus likely to increase the frequency of interactions between the government and private property owners and might thereby affect property owners' perceptions of the extent to which they are engaged in repeat games. Easy access to liability rules might therefore undermine the boundary between the public and private sectors, at least where liability rules are regularly used.

10. See Richard A. Epstein, A Clear View of The Cathedral: The Dominance of Property Rules, 106 YALE L.J. 2091, 2097 (1997).

11. Carol M. Rose, The Shadow of The Cathedral, 106 YALE L.J. 2175 (1997). 
This is just speculation, of course. But I do think it is worth exploring the property rule/liability rule issue in the context of public law. The property rule/liability rule framework might be a useful metaphor with which to view larger issues about the role of government. At a more modest level, the implications of repeat games might be generalized beyond the public sector because actors in private law disputes also engage in repeat games. They do so both directly and through their agents, such as lawyers, who themselves engage in repeat games with courts and with other lawyers. But that gets into an agency problem, which is another dimension.

I am grateful for having been provoked to think about these issues and for having been given the opportunity to participate in this conference. Thank you. 
